The training courses, mainly postgraduate. cited in this seetion include many designed primarily for geoscientists from developing countries.

Signifies the first or amended announcement in Epivodes.

\section{UNIVERSITY OF BALLARAT COURSES} IN ECONOMIC GEOLOGY (Ballitrat, Australiat) A range of short intensive courses, detailed below, aimed at practising geoscientists in mineral exploration. Details from Associalte Professor W R H Ramsey, School of Mining, Geology and Metallurgy, University of Ballerat, PO Box 66.3. Ballarat, Victoria 3353, Australia. Phone 053279 261; fitx: 053279 144;

e-mail: sel@fs 3 ballarat.eduau

\section{EPIGENETIC MAGMA-RELATED}

MINERALISATION IN THE SOUTH-WEST

PACIFIC (2-4 October 1996) Covers gold and copper in epithermal and porphyry style deposits concentrating on physico-chemical processes in relation to geological controls.

WESTERN LACHIAN GRANITE (10-11 October 1996) Granite mineralogy, emplacement and associated ore mineralisation.

TECTONIC ENVIRONMENTS OF GOLD ANI BASE METAL DEPOSITS THROUGH TIME (17-19 February 1997) Ore genesis will be linked to tectonic environment through time.

\section{IMPERIAL COLLEGE COURSES IN} MINERALS AND PETROLEUM (London UK) A range of courses. outlined below, in mineral and petroleum resource appraisal, development and management

Details from Sally Verkaik. Continuing Education Centre. Imperial College, Room 558 Sherfield Building. Exhibition Road, London SW7 2AZ UK. Phone: $+44(0) 1715946882 / 1$ : fax: $+44(0) 1715946883$;

c-mail:cpd $\stackrel{a}{a}$ ic.ac.uk

MINERAL DEPOSIT EVALUATION (I. Ondon.

UK) Two 5-day short courses for individuals who hold technical and financial appointments in mineral resource organisations responsible for mineral exploration and mine preproduction development.

\section{TECHNICAL, FINANCIAL AND LEGAL} APPRAISAL OF MINING PROJECTS (20-22 November 1996) A 3-day short course for fund and asset managers, analysts and bankers involved in mineral appraisal, financing and development.

\section{PETROLEUM ENGINEERING-AN} INTEGRATKI) APPROACH (May 1997) A two-week modular programme introducing scientists and engineers to the wide range of disciplines involved in the appraisal, development and management of hydrocarbon resources.

\section{RESERVOIR SIMULATION: ESSENTIAL}

TECHNOLOGY FOR RESERVOIR MANAGEMENT (15-19 July 1996) A 5-day short course designed specially for geoscientists, who are or will be working in multi-disciplinary teams and who wish to improve their reservoir enginecring and simulation skills.

\section{ZEOSCIENCE SHORT COURSES AND}

WORKSHOPS (various locations in Canada). Courses covering most aspects of geoscience, mostly $2-3$ dilys, some longer, up to 2 weeks. Details from Geological Survey of Canadi.
Training Courses. 601 Booth Street, Ottawa, Ontario K1A OS2, Canadla.

W WATER RESOURCES ENGINEERING (Leuven and Brussels, Belgium). One-year diploma course and two-year MSc degree course in water resources engineering, the latter with options in hydrology, irrigation and water quality management under IUPWARE:

Interuniversity Programme in Water Resources Engineering. Fellowships alvailable : enquire at Belgian embassies. Language: English. IUPWARE organises also annually a Summer School (July-September) on micro-computer applications for water resources management. Details of Diploma Course from IUPW ARF - Institute for Land and Water Management (KUL ), Vital Descosterstraal 102, 3000) Leuven, Belgium.

Details of MSc Course from IUPWAREI aboratory of Hydrology, VUB, Dienst Hydrologic, Plcinlaan 2, 1050 Brussels, Belgium.

Details of Summer School from IUPWARE Institute for Land and Water Management (KUL), Vital Decosterstraat 102.3000 Leuven. Belgium.

Web site:

http://wwwtw.vub.ac.be/ond/hydr/pantar/home page.htm

HYDROLOGY (Hungary. and elsewhere). Sixmonth, postgraduate, diploma course on advanced, theoretical and practical hydrological methods in water-resource management. Part of UNESCO International Hydrological Programme.

Details from DrG Kieniť, VITUKI Water Resources Research Centre, H-1453 Budipest, Pf 27. Hungary. Fax 3612153043.

GEOLOGICAL DATA PROCESSING AND MINE MANAGEMENT (Sydney and World Wide) A range of posigraduate short courses and international special customised training programs that could be credited toward Masters and Graduate Diploma degrees and Certificates. Details from Dr Mike Katz. Director. Key Centre for Mines, University of New South Wales, Sydney NSW 2052, Australia Phone: 61 23855006 ; fax: 6123137260 ):

e-mail: M.Katz@unsw.edu.au

\section{DPEROLEUM EXPLORATION AND} RELATED SUBJECTS. (Rueil-Malmaison, France). A range of short seminars and longer courses in geology, geochemistry, and logging geophysics for engineers, managers and technicians in the petroleum and related industries. Languages: French and English

Details from École National Supérieure du Petrole et des Moteurs, Centre d'Exploration Pétrolière. ENSPM-Formation Industrie, 232 avenue Napoléon Bonaparte, 92500 Rueil-Malmaison France. Fax +33 (1) 47527079 .

PETROLEUM EXPLORATION GEOLOGY (Lincoln, UK). A series of short (up to 5 days) courses for geologists and geophysicists involved with exploration and development programmes that have moved into mature phases. Courses cover seismic interpretation, structural geology and hasin modelling. Details from Badley Earth Science Ltd, North Beck House, North Beck Lane, Hundlehy, Spilsby. Lincolnshire PE23 5NB. UK. Phone: +44 1790 753472; fax: +441790 753892 .

\section{PROFESSIONAL DEVELOPMENT} SEMINARS IN MINERAL ENGINEERING AND MINERAL ECONOMICS. Conducted by the Department of Mining and Metallurgical Fingineering, McGill University. Language: English.

Details from Normal Procyshyn, Coordinator of Professional Development Seminars, Department of Mining and Metallurgical Enginecring. McGill University, 3480 University Street, Montreal. Quebec H3A 2A7. Canadal. Phone: (514) 398 4383; telex: 05-268510; fax:(514) 398-8379.

\section{QRECENT DEVELOPMENTS IN QUANTI-} TATIVE AND SEQUENCE STRATIGRA$P H Y$. Short courses (the next, of 5 days. in Copenhagen. Denmark in September 1997) organised by the Commitlee for Quantitative Stratigraphy which is part of the IUGS's International Commission on Stratigraphy. Details from Dr F P Agterberg, Geological Survey of Canada, 601 Booth St., Ottawa KIA OF8, Canada. Phone: (1) 6139962374 ; fax: (1) 61.3996,3726: c-niail: agterberg@gsc.emr.ca

\section{SEPM CONTINUING EDUCATION}

COURSES (various locitions USA). Short 1 or 2 day courses in advanced aspects of sedimentary geology. petroleum geology and hydrogeology for practising geoscientists wishing to keep abreast of new developments and techniques.

Details from SEPM Continuing Education Department, PO Box 47.56, Tulsit, OK 741590756, USA

\section{W SHORT COURSES IN PETROLEUM} GEOLOGY AND RELATED DISCIPLINES Conducted by IHRDC in London or Aberdeen. UK. Languagc: English. A series of short courses helween three and five days on seismic interprelaion. reservoir modelling and reservoir management. Next round of courses in Autumn 1996.

Details from IHRDC / Amsterdam, Brouwersgracht 288, 1013 HG Amsterdam, The Netherlunds. Phone 312063801 10: fax: 3120 6.385298 :

e-mail: 101762.1027 (๓) compuserve.com

\section{RESERVE ESTIMATES IN THE REAL}

WORLD. Three-day course conducted periodically under the auspices of the Society of Economic Geologists for all atsociated with ore reserve estimation from exploration to development. Next course 10)- 12 September 1996. Staffordshire University, UK. Details from Mrs E A Reeves, School of Sciences, Staffordshire University, College Road, Stoke-on-Trent ST4 2DE. UK. Phone: $\div 44$ (0) 1782 294859: fax: +44 (0) 1782745506 ; c-mail: d.e.roberts (r) staffs.ac.uk

TWAS FELLOWSHIPS AND RESEARCH GRANTS. A series of grants for developingcountry geoscientists of proven ability to work and study for periods of $1-12$ months at centres of excellence in the South, and to purchase equipment and laboratory supplics for research projects specified by them.

Details from Executive Director, TWAS Secretariat. Third World Acudemy of Sciences (TWAS), c/o International Centre for Theoretical Physics (ICTP). PO Box 586. 34100 ) Trieste, Itaiy. Phone: +3940 2240-327; fax: +3940224559 ;

e-mail: twas $($ ictp.trieste.it: www home page: htp//www.ictp.trieste.it/ twas/TWAS.html

WEDC (Water. Engineering and Development 
Centre). Concerned with water and urban infrastructure. Courses offered range in duration from 3 weeks to 12 months, deal with a wide variety of water, engineering, developmental environmental, and management topics, and lead to certificates, diplomas, or MSc degrees. Details from Kathy Brown, WEDC

Loughborough University, Leicestershire LEI 3TU, UK. Phone: +(44) 1509 222885; fax: +(44) 1509211079 email: WEDC (a) Iboro.ac.uk

口COMPUTER ASSISTED TRAINING IN MINERAL RESOURCES DEVELOPMENT (Fontainebleau, France), 4 weeks (annually). Next course 1st-30th April 1997. Languages: French and English. Closing date for applications I March 1997.

Details from: Professor I. Zanone, Ecole des Mines de Paris, 35, rue Saint Honoré E9, 77,305 Fontaincbleau Cedex, France, Fax: (1) 646947 11; e-mail: sauzay@cges.ensmp.fr.

BGS COURSES IN EARTH SCIENCE (UK and worldwide as specified by client) Language: English. A wide range of shortduration (up to 10 days) practically orientated. postgraduate, training courses to assist national and international personnel to resolve problems involving earth sciences.

Details from Dr lan E Penn, Coordinator. Training, Research and Development, British Geological Survey, Keyworth, Nottingham NG12 5GG, England. Tel: $+44(0) 115$ 9363187; Fax: $+44(0) 115-9363150$.

E ENVIRONMENTAL AND SAFETY CONCERNS IN MINING ACTIVITIES (Alès. France). October to June (annualiy). Language, French
Details from Dr Gérard Verraes, Ecole nationale supérieure des techniques industrielles et des Mines d'Alès, 6, avenue do Clavières, 30319 Alès Cedex, France. Telefax: 3366785034 ; phone: 3366785196 ;

e-mail:gverraes@ensm-ales.ir

ITC COURSES IN EARTH SCIENCES PHOTOGRAMMETRY, AND REMOTE SENSING. Conducted in The Netherlands by ITC (International Institute for Aerospace Surv:sy and Earth Sciences). Language English. Details from ITC, PO Box $6,7500 \mathrm{AA}$, Enschede. The Netherlands. Phone: +31 (0)53 4874 444: fax: +31 (0)5348 74 400): telex: 44 525 ITC NL

INTRODUCTION TO DIGITAL IMAGE PRO. CESSING July (annually) 4 months.

EXPLORATION GEOPHYSICS August (annu ally) 9 months for postgraduate course, 21 months for MSc course.

APPLIED GEOMORPHOLOGY AND ENGI NEERING GEOLOGY. September (annually) 10 months for the postgraduate course, 21 months for MSc course

MINERAL EXPLORATION August (annually) 9 months for postgraduate course, 18 months for MSc course

ENGINEERING (GEOLOGY August (annually) 11 months for postgraduate course. 22 months for MSe course.

GEOLOGICAL SURVEY September (annually) 11 months for postgraduate course, 20 months for MSc course

REMOTE SENSING APPLICATIONS FOR EARTH SCIENCES November (annually) 2 months.
GEOINFORMATION SYSTEMS FOR CADASTRAL, URBAN AND RURAL APPLICATIONS, 12 months for professional Master degree course, 18 months for $\sim \mathrm{MSO}$ course.

Other organisations that offer specific training courses in a variety of earth-science-related fields:

GDTA (Groupement pour le Développement de la Télédétection Aérospatiale), 18 avenue. Edouard-Belin. 31055 Toulouse Cedex, France. Phone: (33) 61274288 : fax: (33) 61281498 ; e-mail: patricia@venus.cnes,gdta,fr

ESRIN (European Space Agency) Via Galileo Galilei, 00044 Frascati, Rome.

GSA (Geological Society of America) Continu ing Education Cordinator, 3300 Penrose Place. PO Box 9140, Boulder CO 80301, USA.

IIGAC (Instituto Geográfico 'Agustin Codazzi'), Apartado Aéreos 53754 y 6721 . Bogotá 2. Colombia. Fax: (571) 3680950 .

DISEE (International Institute of Seismology and Earthquake Engineering), Building Research Institute, Ministry of Construction, 1 Tatehara, Tsukuba, 305, Japan. Phone: +81 298-64 6677, +81 298-64 2151(switchboard) ext 450): fax: +81 298-646777 (Aun Ken Sudo) Four courses are available:

- 11-month course for young seismologists and carthquake engineers:

- Two-month course (bicnnialy) for advanced experts;

- Individual course for advanced experts to a maximum of one year; and

- 45-day course in global carthquake observation.

UNESCO (United Nations Educational Scientific and Cultural Organization), 7 place de Fontenoy, 75700 Paris, France.

\section{PUBLISH in Episodes your international showplace}

Boot-up your computers and tell the world about your meetings, publications, training courses, discoveries, inventions, ideas and accomplishments.

Send contributions to:

The Editor, Episodes c/o British Geological Survey, Keyworth, Nottingham NG12 5GG, UK

Fax: +4401159363385

e-mail: mbs@wpo.nerc.ac.uk 